\title{
Research on Penetration of Anglo-American Culture in University English Teaching
}

\author{
Li Yifei \\ Bohai University, Jinzhou, Liaoning, China, 121013 \\ liyifei163.com
}

Keywords: Anglo-American Culture; university English teaching

\begin{abstract}
Anglo American cultural background knowledge is the basic foundation of the correct understanding of words, sentences of English. This paper expound the necessity of penetration of Anglo-American culture, analyses the concept of the Anglo-American culture, points out the principles of penetration of Anglo-American culture in university English teaching, and finally gives the methods of introducing Anglo-American culture in university English teaching in order to give relevant researchers some references.
\end{abstract}

\section{Necessity of Penetration of Anglo-American Culture}

Language is a special part of culture. It is a tool for people to communicate with each other, and a medium integrating people and culture. Language is formed along with the formation of human society, but also with the development of human society. Human language has created a culture, culture and in turn promote the development of human society, but also enriched the way of language expression. Since ancient times, the cultural heritage of human society has accumulated a deep imprint on the language. Anglo-American culture refers to the sum of the life styles of Anglo American countries, people's way of life, including the geographical environment, social history, customs, traditions and customs, folklore, way of life, literature and art, religion, science and technology, concept of value.In the current practice of university English teaching, the teachers only focus on teaching listening and speaking, reading and writing skills knowledge, teachers are to teach a variety of knowledge or outline of test, students in the back of the machinery, learn boring, almost no interest whatsoever when British and American culture deeply in the teaching, Anglo American countries fresh and new culture, customs can effectively stimulate students interest in learning, arouse their learning initiative. University English teaching, fundamentally speaking, is to apply, did not achieve this effect, then the high score can show his success as mentioned above. The language is produced and developed in the cultural environment, he is the expression and reflection of culture, which determines the different language and culture have great difference in the English Teaching of culture, so that students can master the correct form of the language, so that they can be on different occasions, according to different objects, according to different needs, the process of communication activities for cultural infiltration of the linguistic forms, rich cultural background knowledge provides conditions for the meaning construction, make students the main body of knowledge. The teacher's task is to guide and organize students to collaborative learning, not only focus on the vocabulary and grammar, but also have a good command of Anglo-American culture.

\section{Concept of Anglo-American Culture Penetrated in University English Teaching}

\section{Anglo-American Background Knowledge}

All countries have their own basic background knowledge. The United Kingdom is no exception. This kind of knowledge is often referred to as the fact culture. This kind of knowledge can make the students have a general understanding of the Anglo American culture. Teachers should guide students gradually find and accumulate some British and American culture, and guide them to use the knowledge to express their knowledge. Such as the UK, the student must first understand the British in history is very powerful, is known as the "British Empire".GreatBritain is composed of 
three blocks of England, Scotland, and Wales. Because of the largest England area, the most economically developed, London is the capital, and therefore the general use of England on behalf of the entire United Kingdom. Conservative Party and the LaborParty are the UK's political parties. Under the monarchy system, royal, noble, the House of Lordsand the House of Commons, real power is grasped by the Prime Minister. In the history of the industrial revolution the earliest in the United Kingdom, the United Kingdom of the shipbuilding industry is famous in the world, is a veteran of the industrial countries. British social welfare is good, unemployment insurance is relatively high. Cambridge University and Oxford University are the famous universities of British Higher Education.

\section{Anglo-American Folk Customs}

Customs is formed and accepted in the daily life of the majority of members in a particular group during a long time. It includes the basic habits of people, involving all aspects of life. Various ethnic customs have very big difference. For example, in China, people greet said to care for each other, the common idiom are "what are you doing recently?" or "Where are you going now?" or "Have you had dinner yet? Chinese even ask others get married or not, now how much income and children recently you wait, this is friendly and caring but said Britain is incomprehensible to the style and language, and even disgust, because they think it is their private life, these words are interfering in their privacy, that the right of privacy, this is very not educated this is the embodiment of cross-cultural awareness. To understand these are helpful for people to easily cope with cross cultural communication. To be polite and appropriate in the usual class, the teacher can gradually introduce some of the habits of daily communication. Calling language also a typical difference is Chinese people like to let the children call stranger called brother, sister, uncle, aunt and other. This is the Chinese civilization that there is a family or kinship between each other. In the English speaking countries, the children call a stranger, generally called Mr. or Miss Mrs., Ms. Seldom heard Smith aunt, Janet uncle and so on. These differences are expressed as a language. It is particularly worth mentioning the weather with the British. Britain said the weather in England for the weather, and not climate, mainly because the British weather is changeable. There are four seasons in a day, so British typical cartoon image is wearing a hat, wearing a windbreaker, feet wearing high boots and long umbrella in hand, the image is that they go out to the changeable weather made full preparations. Britain has a temperate climate, the British gentle, even a little cold, reticent, but as long as you and the British people to talk about the weather, you will found they each is talkative master. When talking about the weather, if the British people say "It's a little cold, isn't it?"You'd better echo he said yes and answer "Yes, it is." If you say no, it will be an embarrassing moment.

\section{Anglo-American Words Connotation}

In two kinds of cultural exchanges, the two sides will inevitably be used to many idioms. So the teaching content of British and American culture should also include common idioms and idioms in English. In English, there are some stories that can be used as a fun English to students, to stimulate students' interest in English learning. If students can easily be translated into white elephant and the Chinese do have a white elephant, elephant battery, instant noodles. In Chinese, the white elephant is precious. But in English, elephant white is a story. Thailand is famous for its rich elephants. The white elephant is extremely rare, is regarded as a rare animal. The king said that all the elephants are owned by him. There is an ancient legend of the king of Thailand to a minister of discontent, will be a white elephant as the Minister for heavy ceremony, in order to punish him. They are regarded as supernatural beings. They shall not be transferred and made work. After a considerable period of time, it became a master's burden, to pay a heavy price, even the master dissipate one's fortune. So the white elephant a in English is a metaphor for things that are a lot of money that can be consumed, but not useful, and something that makes people feel a burden and a burden. So in English a white elephant is not likely to become a trademark of the goods. 


\section{Principles of Penetration of Anglo-American Culture in University English Teaching}

\section{Systematic Principle}

At present, teachers still attach great importance to the pronunciation, grammar, semantics, and paragraph in the process of language teaching, ignoring the cultural phenomenon in the language material. When the teachers introduce the Anglo-American culture, they may teach it free, as they in practical situations how to apply is rarely mentioned. In the language teaching system, Anglo-American culture knowledge can be penetrated in the following three aspects precede: Firstly, the differences in the aspects of daily life in English and Chinese culture, and in the use of language forms and the specific performance. Secondly, teachers can show differences caused by cultural differences between English and Chinese words, idioms significance and application. Thirdly, teachers can introduce western modes of thinking, interpersonal relationship and language expression of cultural connotation, and appropriate use of language to improve their communicative competence in English.

\section{Practical Principle}

Anglo American cultural background knowledge is the basic foundation of the correct understanding of words, sentences and discourse plays a role, of course, is important, but should not be in to teach the culture and teaching culture misunderstanding, it must be made clear is cultural introduction is carried out within the framework of language teaching, the purpose is for the language teaching, so the teaching of culture should follow the principle of utility. This requires teachers to students, taking into account the actual needs of, the cultural background knowledge and teaching content organic to combine, consciously to penetrate into the specific vocabulary teaching, discourse teaching of cultural knowledge. This way can not only let students understand the cultural background knowledge, but also increase the English learning interest and gradually lovereading British and American literary works.

\section{Periodic Principle}

Periodic principle requires the penetration of the Anglo-American culture should follow the principle of gradual and orderly progress. Teachers should give full consideration to the student's language level, cognitive ability and the according to the students' language development level and ability to accept, the shallower to the deeper, from the outside to the inside of a gradual approach, let students fully understand the content of cultural study of nature. For students in the learning process problems and content of the text, related to the cultural background of timely explanation or cultural differences, comparing and analyzing the reasons, to avoid a mistake again. Teachers can introduce the Anglo-American culture from the introduction of the daily lives of the people of English speaking countries, and then gradually penetrate their cultural background, history, geography and so on.

\section{Approaches of Penetration of Anglo-American Culture in University English Teaching}

\section{Direct Penetration}

The language environment of students learning English is mainly in the classroom. They usually have few learning and use of English opportunities and the environments. In the context of the cultural background knowledge, students often feel difficult to understand. In this case, teachers should play the leading role, directly to introduce students to the cultural background knowledge, when preparing a lesson select some teaching related typical cultural materials and their right to use to the classroom, to enhance the teaching of knowledge and interest, and the depth and breadth of learning content and arouse the students' thirst for knowledge, active classroom atmosphere. English teachers should fully developed using the current English textbooks, attach great importance to the teaching of cultural communication, enhanced the students' sensitivity of cultural if talked about Halloween, students can be asked to make home masks and pumpkin lights, to the school to engage in a Halloween party; When the material of teaching involves theThanksgiving day, teachers can ask students to write their own parents warm greeting cards, and addressthe origin of the festival. 


\section{Extracurricular Reading}

Anglo-American culture is rich in content, involving all aspects of life.Teacher could not mention all the relevant cultural background knowledge in the classroom, then in order to expand students' knowledge, effectively increased the knowledge of language and culture, teachers must guide students in extra-curricular reading. Teachers may choose to recommend some good books and magazines to the students in the social and cultural background of the British and American countries. Such as "British culture and modernization", "American culture and modernization", "language and culture", "English learning culture background", "Twenty-first Century". In addition, students are encouraged to actively participate in English activities, guide them to engage in English corner, English salon, and proactive contact with foreign teachers, inviting foreign teachers in extracurricular open seminars, such as Anglo-American culture, American historical background. In the process of the teaching, if students encounter some knowledge of the Anglo-American cultures, they can ask the teachers to solve the problems.

\section{Multimedia Teaching}

Improvement of the reform of English teaching method and teaching means should applied in the penetration of the Anglo-American culture. Slide projector, film, television, video and DVD began to teaching, and the computer multimedia technology into the classroom, has injected new vitality to teaching. Multimedia teaching is to set up audio-visual class weekly to students play video teaching, teaching scenes, musical, entertaining. Open FM English radio programs. Play the recording materials, create atmosphere for learning English, to learn English to students learning, life, rest and entertainment and so on various occasions in the infiltration and the students in the school at any time and English dealing and subtle. Watching English movies is one of the best ways to improve students' language skills and to understand the culture of the English language.

\section{References}

[1] Wang Haiyan. The Penetration of Anglo-American Culture in English Teaching. J. Journal of Anshun University. 2012(2):77-79

[2] Zhang Heqiong. On Grasping Anglo- American Culture Knowledge and English Teaching. J. Journal of Jiangxi Normal University(Social Sciences).2004(8):120-124

[3] Deng Jianhui. On the Effective Tactics of Strengtheningthe College English Majors' Attainments of British and American CulturesJ. Journal of Gannan Teachers College (Social Sciences).2004(5):128-131 